\title{
Impact of Corporate Governance on Firms' Financial Flexibility in the Emerging Economy: Evidence From Bangladesh
}

\author{
Md Rashidul Islam (Corresponding author) \\ Doctoral Student, School of Accounting \\ Dongbei University of Finance and Economics \\ 217, Jianshan Street, Dalian, Liaoning Province, China \\ Assistant Professor (on study leave), East West University, Dhaka \\ E-mail: rmislam2002@yahoo.com
}

\author{
Man Wang \\ Professor, School of Accounting
}

Dongbei University of Finance and Economics/Internal Control Research Centre in China 217, Jianshan Street, Dalian, Liaoning Province, China

\section{Muhammad Zulfiqar}

Doctoral Student, School of Accounting, Dongbei University of Finance and Economics 217, Jianshan Street, Dalian, Liaoning Province, China

Received: August 31, 2019 Accepted: November 6, 2019 Published: November 11, 2019 doi:10.5296/ijafr.v9i4.15370 URL: https://doi.org/10.5296/ijafr.v9i4.15370

\begin{abstract}
Corporate governance has a positive impact on firm performance. Financial flexible firms are a better performer when there are financial constraints as well as financial crises. However, what motivates financial flexibility is a dearth research area in the existing finance literature. The objectives of this research are to investigate the relationship between corporate
\end{abstract}


governance and financial flexibility; how corporate governance influence financial flexibility; and, what factors of corporate governance are dominant to influence financial flexibility. To pursue the research objectives we chose Cement Industry of Bangladesh as a case. We consider liquidity, Internal Funds and Unused debt capacity as the proxy of financial flexibility and Ownership Concentration, Board Size, Board Independence as Corporate Governance variables and Firm Size, Market to Book Ratio, Debt Capacity, Financial Constraints and Firm Age as control variable to estimate the relationship between corporate governance and financial flexibility. This study evidences that Board Structure has no significant influence on firms' cash holding (Liquidity). However, Firms Age and Market to Book Value have a significant influence on firms' cash position. This study also finds that Ownership Structure has no positive impact on Firms' Unused Debt Capacity but Financial Constraints and Market to Book Value have a positive significant impact on firms' unused debt capacity. However, Firm Size has a positive relationship with Internal Funds.

Keyword: Financial flexibility, Cash holding, Leverage, Internal financing

\section{Introduction}

In the wake of series of corporate failures in US (e.g., Enron, WorldCom) and Italy (e.g., Parmalat) and rest of the worlds, corporate governance has received increased attention in the past few decades (e.g Chen and Hsiao, 2014). These business scandals revealed and pointed out prevailing agency problems of those companies based on nature of ownership structure (whether overly disperse or concentrated) (Note 1) that lead to severely agency problems((Coffee, 2005). Therefore, exploring whether of how corporate governance can mitigate agency costs and enhance financial flexibility to avoid corporate failures is a worthy work.

It is a great puzzle in capital structure research for financing debt or equity considering the trade-off between bankruptcy costs and tax shields. Firms' behavior regarding financing decision largely depends on the time of financial constraints and unconstraint. On the other hand, investment greatly depends on firm's debt capacity and unused debt capacity. A potential explanation of this phenomenon is the preference of financial flexibility (Jong, Verbeek and Verwijmeren, 2012). The idea came from the optimal capital structure proposition of Modigliani and Miller (1963) terming financial flexibility as "reserves of untapped borrowing power" and revealed that firms do not use borrowed capital as much as anticipated despite the income tax shield due to saving debt capacity in order to keep flexibility to respond future capital necessity. This created a flexible theory in the field of finance and is now called financial flexibility. It expresses the firm's ability to re-act financing needs as means of accessing external funds at an economic rate and restructure the capital structure (Gamba and Triantis, 2008).

It is argued that financially flexible firms have better capability of availing external financial resources in response to unexpected economic events, investment opportunities and maximize company's value (Cherkasova and Kuzmin, 2018; Ma and Jin, 2016; De Angelo and De Angelo, 2007). These firms always attempt to hold better cash position to grab investment opportunity. However, the mechanism works for being financially flexible to 
carefully consider cash dividend policy, leverage, capital structure, liquidity and investment (Gamba and Triantis, 2008). Financially flexible firms paying cash dividend have lower investment reduction than firms without flexibility (Daniel et al., 2008). Consequently, cash dividend decision is crucial for firm's growth as it decreases firms net worth increasing investors' personal net worth. It may also curb firm's expansion strategy and firms should carefully choice dividend policy (Dewri et al., 2015) for being financially flexible. Similarly, financially flexible firm's hold a low level of debt that gives them strong strength to combat risk and chances of default (Bates et. al., 2008).

The importance of being financially flexible comes from the notion that it is the one of the best tool used as intangible assets of the firm (Kuo et al., 2006) to combat firm's economic problem. It is argued that about $86 \%$ of the financially constrained firm's postponed or cancelled their planned investment during the financial crisis(2007-2008) and sold their assets to fund their firm's operating activities (Campello et al., 2010). In contrast, financially flexible firms outperform non financially flexible firms and value of the firm has a positive association with financial flexibility during the financial crisis (Tong and Wei,2008). However, firms with high financial flexibility underperform in the down market and there is no association between excess flexibility and future profitability (Simutin, 2010).

Financial flexibility is also important as it is used by the credit rating organization to assess the firm's strength over its competitor as it is very crucial to avail funds from lenders (e.g. Cherkasova and Kuzmin, 2018). It is highly relevant to the developing coungtries as developing economies stimulate new investment opportunities that demand executives to explore tools for increasing the financial flexibility in order to meet additional resources for support their business development.

The objectives of this research are to explore the relationship between corporate governance financial flexibility; how corporate governance influence financial flexibility; and, what factors of corporate governance are dominant to influence financial flexibility. First, we show the relationship between theories and financial flexibility from existing literature and discuss the relationship between cash holding, leverage, payout policy and impact on firm performance during and after financial crises. Second, we discussed the relationship between Board Structure and Cash Holdings, Ownership Structure and Leverage, Firms' Size and Internal funds and developed hypothesizes. Third, we test hypothesizes and explain the results and finally, we conclude with our findings.

\section{Literature Review and Hypothesis Development}

\subsection{Theoretical Framework of Financial Flexibility}

Cash holdings, internal funds, and spare leverage capacity have been used as the proxy of financial flexibility in the contemporary capital structure literature (Arslan et al., 2014; Ma \& Jin, 2016). Leverage and cash used to be closely associated as leverage provides more access to the cash and the significance of liquidity to access in financial flexibility leads to the Keynes liquidity preference theory (1973) and inventory management theories of Baumol (1952) as a key theoretical foundation of financial flexibility framework. 


\section{MlMacrothink}

International Journal of Accounting and Financial Reporting

ISSN 2162-3082

2019, Vol. 9, No. 4

Cash holding has a transaction cost savings and precautionary motive benefits (Keynes,1973) as raising funds through issuing initial public offering, right share offering or bond issuing requires permission from the regulators and involves underwriter and other costs. If the firms have excess cash then managers can use them for funding continuing operations and extended investment opportunities even if others sources of finance unavailable which also studied by Myers and Majluf (1984). Keynes (1973) evidenced that for an agreed net debt there is an optimal volume of cash where cash is not merely net debt.

Few more early research of liquidity is Baumol (1952) and Miller and Orr (1966). Baumol (1952) proposes a model of weighted benefits of cash holding and suggests cash is an asset and needs to be managed like other tangible assets as converting other tangible assets into cash involves high costs. These two theories suggest liquidity and spare debt capacity is a critical driver of firm's financial flexibility

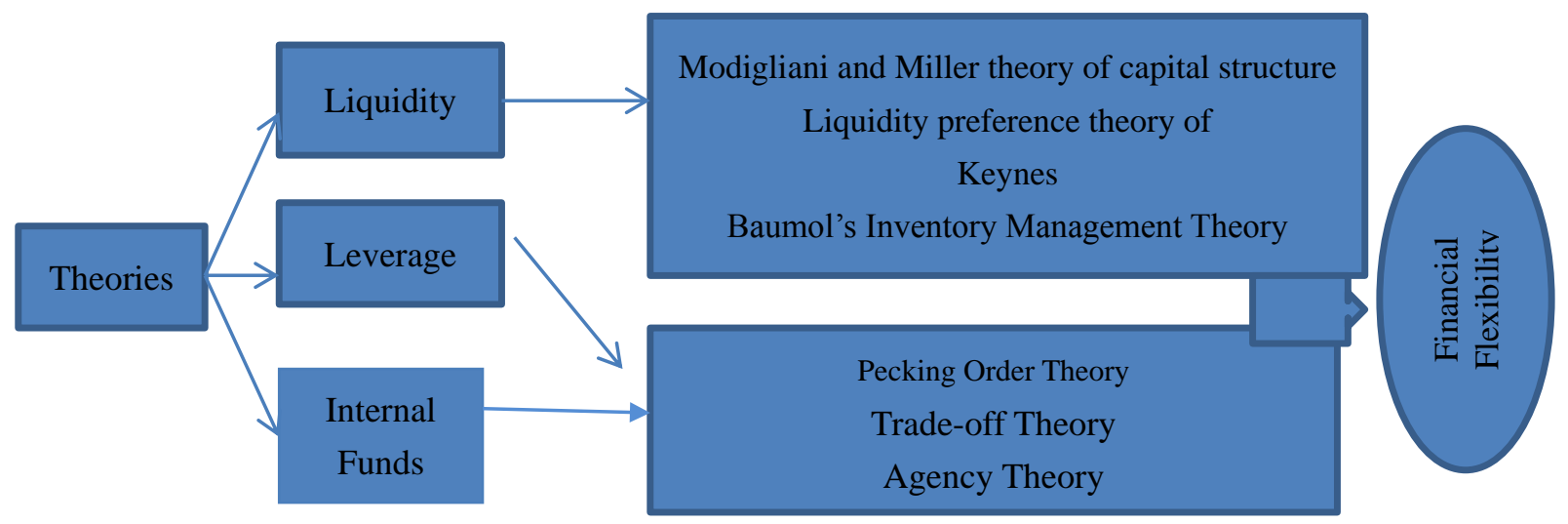

Source: Islam, Wang and Dewri (2019)

Modigliani and Miller (1958) suggest that in the perfect capital market, the absence of transaction costs, taxation, different borrowing costs, bankruptcy costs and symmetry of market information, the firm value is not dependent on capital structure decision. Instead, they argued that firm value is dependent on earning power and by the risk of underlying assets. This proposition implied that firms can generate required funds when necessary and requisite for improving and sustaining financial flexibility will drop. However, the underlying assumptions of this theory are no longer valid in the real world practices and it's used in the imperfect capital market is questioning. Moreover, financing decision is relevant and the essence for financial flexibility is demanding when cash flows and investment opportunities are uncertain (Byoun, 2011). While funding opportunities are uncertain for profitable projects and firm wants to maximize its value financial flexibility become extremely important as the term financial flexibility is associated with the ability of availing and reformation the financing strategies without plummeting appreciated investment opportunities (Byoun, 2011).

According to trade off the theory of capital structure, companies should select funding source based on balancing cost and benefit. More precisely, the theory proposes that firm select the level of debt balancing tax advantages of debt with the augmented cost of potential bankruptcy (Kraus and Litzenberger, 1973; Myers and Majluf, 1984). Similarly, pecking order theory (Myers and Majluf, 1984) of capital structure suggests financing source based on 
the risk involved and proposed that firm should choose the internal source (retained earnings) followed by borrowed funds and equity issues as last resort. Seemingly, these theories propose different types of funding sources and demonstrate the situations where a firm can choose debt or equity as a financing source. However, those theories did not consider the market conditions and financing opportunities and market timing hypothesis have been developed and it suggests that whether firms should finance their investment with debt or equity based on market condition (Powers and Tsyplakov, 2008). These make financial flexibility more significant areas of study to face the financial needs and resist in the organization critical financing time.

\subsection{How to Avail Financial Flexibility?}

Leverage seems to be one of the most important determinants of financial flexibility. It is argued that financial flexibility can be obtained by adopting low leverage policy and suggesting that preserving low leverage ratio can generate the capacity of future borrowing power and create room for enhancing of leverage ratio (Goldstein et. al., 2001; Byoun, 2011). Conversely, financial flexibility can also be obtained through holding excess cash (Opler et al., 1999; Almeida et al., 2003; Harford et al., 2005; Riddiek and Whited, 2009). They argue that holding ample of cash gives the opportunity to exploit chances of good investment enhancing firms' growth opportunity and protect firms from the adverse situation (Riddiek and Whited, 2009). However, recent literature suggests that adopting the above two policies (Low leverage \& High cash holdings) can lead to better financial flexibly and avoid the distress of financial shake and default (Bates et al., 2009; Byuon, 2011)

Corporate payout policy is also one of the significant determinants of financial flexibility. It is argued that firms' employ dividend policy preserve financial flexibility. Distribution of cash dividend is a strategic tool to exploit internal funds when facing downturn of operating performance and potential investment opportunity (DeAngelo and DeAngelo, 2007; Oded 2008). In contrast, holding excess cash may lead to cash abuses and agency benefits. As a result, firms have a tendency to distribute dividends or repay debt. Nevertheless, dividend policy acts as a tradeoff between preserving financial flexibility and abolition of agency costs (Liu, 2017).

Augmenting financial flexibility to face the funding needs of valuable investment opportunities few more ways were prescribed by extant literature. Using commercial paper (Kahl et al., 2008) could be one of the best ways of enhancing financial flexibility who does not want to face costs regarding registration with stock exchanges. Similarly, bank borrowing over bond financing is a favorable way for firms with high demand for flexibility (Freixas, 2000). Additionally, firms can raise their financial flexibility by retiring debt by using callable bonds (Powers and Tsyplakov, 2008). However, issuing or retiring debt depends on firm's condition of financial surplus or deficit. Additionally, firms can enhance financial flexibility by augmenting their retention limit (Eldomiaty and Azim, 2008). Firms can preserve more of their net income when the cost of equity funding is comparatively low. 


\subsection{The Relationship Between Financial Flexibility and Firm Performance}

Generally, firms with significant financial flexibility have solid cash flows, strong balance sheets and access to low-cost debts. It is yet to empirically discover whether financial flexible firm leads to strong financial performance in the normal time. Additionally, it is also unanswered whether firm performance varies with the firm characteristics. However, it is argued that during financial crisis financially flexible firms can approach better investment opportunity and perform better than financially inflexible firms (Arslan et. al., 2014).

Multinational companies and local company's performance based on financial flexibility may differ as international firms have to face foreign government regulation, policies, changes of environment and culture (Miller,1993).Nevertheless, financial flexibility plays significant and positive effects on multinational companies performance during the financial crisis and handle external shocks with not significant organization structural change (Kuo et. al., 2006)

Firms hold cash for different motives: transaction, precautionary and speculative. Cash and cash equivalents supposed to be the best liquid assets and it does not merely generate earnings either investing or spending for firm operation. Moreover, holding excess cash could enhance the opportunity costs and Jensen and Meckling (1976) propose in agency theory that there is an opposite relationship between cash holding and firm value. However, holding cash at the desired level is critical to how financiers observe and evaluate the firm (Kao, 2012).

According to Mahrt-Smith (2007) cash holding and firm value depends on corporate governance and documents that if cash in position is to finance operating activities and offer a buffer external financing costs then holding cash is a good choice. Conversely, when the corporate governance is poor holding cash may be disadvantageous to the cash value. However, corporate governance features like a small percentage of external directors in board and large board size may lead potential embezzlement and responsible for negative relation between cash holding and firm value (Lee and Lee, 2009).

Information asymmetry plays an important role to decide to hold cash and firm performance. High asymmetry of information leads to low cash holding and vice versa (Drobetz et al., 2010). Pecking-order theory and the transaction costs theory also suggest that there is a positive association between firm value and cash holdings.

\subsection{Hypothesis Development}

\subsubsection{Board Structure and Cash Holding}

Board structure is a vital element of a firm as it has the power to guide, monitor and assessment of senior management. The effectiveness of the board depends on its size and independence (Harford et al., 2007). However, ideal board size is inclusive in the current literature but suggests that larger board provides a tradeoff of skills and experience of board members and appears to be playing optimal monitoring role when managers opportunistic behavior prevails (Harris and Raviv's, 2006; Raheja, 2007). On the other hand, for the decision-making purposes, small boards are more effective (Yermack, 1996) than larger boards. 


\section{Mll Macrothink}

International Journal of Accounting and Financial Reporting

ISSN 2162-3082

2019, Vol. 9, No. 4

Board composition is also playing a significant role in monitoring and decision making. Inside directors have business-specific knowledge that helps the board to comprehend the firm's business while outside directors (independent directors) have know-how that mitigates managerial fosse and expropriation of firm's assets (Harford et al., 2007). In addition, board independence suggests better monitoring and effectiveness of the firm's activities. In line with these findings, we consider that board size and composition as a proxy of corporate governance structure (Kusnadi, 2011; Harford, et al., 2008).

According to Harford et al (2007), cash holding depends on the strengthening of corporate governance structure in the developed market. They evidenced that weaker corporate governance structure leads to smaller cash retention and has a tendency to avoid dividends and future payout commitments and chose to do investment in capital expenditure and repurchases. However, in the developing markets like Singapore and Malaysia Firms with less effective governance attributes are found to be more inclined to accumulate cash than those with more effective governance (Kusnadi, 2011).

Bangladesh is a fastest growing economy in south East Asia and pronounces corporate governance guidelines in 2006 amended in 2012 (BSEC) where corporate governance environment encourages external influences in the management of the firm. The stock market of Bangladesh is illiquid and institutional investors' participation is minimal and heavily dependent on retail investors and demand of the stocks depends on the fund supplied by the banks and financial institution (World Bank, 2015). It is still developing stage of implementing corporate governance considered it as weak corporate governance form. The business environment in Bangladesh is significantly differing than the other developing countries like China, India, Malaysia, and Singapore. In this situation, we would like to test the hypothesis

\section{$H_{1}$ : Board structure has a positive impact on firms' cash holding}

\subsubsection{Ownership Structure and Leverage}

Ownership structure plays a significant role in exploiting leverage in capital structure decision. It is often used as a substitute for corporate governance in the countries where weak corporate governance prevails (La Porta et al., 1999). Good governance facilitates borrowing at lower costs (Cremers et al., 2004; Klock, et al., 2005) and seemingly leads to higher firm's leverage.

Family ownership helps to reduce imperfection in the capital market (Galeotti et al., 1994) and does a better evaluation of strategic investment projects due to intensive knowledge and prolonged involvement in the business leading to an optimal level of investment (Schulze et al., 2003).This optimal level controls investment behavior and avoids risky external borrowing and control the leverage ratio to preserve flexibility (Jensen and Meckling, 1976). In contrast, institutional shareholders usually have large shareholding and possess stronger incentives and sound skills to monitor management (Grossman \& Hart, 1980) and influence financial policies leading to lower borrowing costs and encourage more debt in the capital structure. Moreover, concentrated ownership may reduce the managerial expropriation and 
reduce the agency costs. Consequently, firms with higher ownership concentration are inclined to use internal funds and reluctant to use leverage and tendency to preserve unutilized debt capacity (Estwick, 2016). In this situation, we like to test the following hypothesis.

\section{$\mathrm{H}_{2}$ : Ownership Structure has a positive association with unused debt capacity of the firms}

\subsubsection{Firm Size and Internal Funds}

Estwick (2016) tests the relationship among corporate governance and financial flexibility and proposes the hypothesis that board size has a positive relationship with firm's liquidity and negative relationship with leverage and internal funds. Similarly, board dependence has a positive relationship with firm's liquidity and negative relationship with firms leverage and internal funds. Additionally, Ownership concentration has a positive association with liquidity but negative relationship with firms leverage and internal funds. He evidenced that high ownership concentration Caribbean firms are linked with the low liquidity but associated with excessive unutilized debt capacity. Additionally, greater board independence has a positive relation with firms' liquidity indicating weak corporate governance increase agency costs (Jensen, 1986)

\section{$H_{3}$ : Firm size positive relationship with internal funds.}

\subsection{Measurement of Financial Flexibility}

In the recent literature Arslan et al. (2014) financial flexibility is a proxy of firms leverage and cash holdings. They suggest that firms with high cash holding and low leverage are flexible firms as these firms as greater ability to raise external funds. Conversely, firms with high leverage and low cash position indicate less flexible firms. Consistent with this approach Ma \& Jin (2016) measures financial flexibility considered firms liquidity, leverage and internal funds. Previous literature suggests index methods. Proponents of these methods tend to use a single index or multiple indexes for measuring financial flexibility. A single index is the index of either leverage Billet, King, and Mauer, 2007; Denis and McKeon, 2009; or cash holdings (Byoun, 2008; Marchica and Mura, 2010; Arslan et al., 2012; Hoberg et al., 2014). On the other hand, Multi-index is the combination of a number of the indexes to calculate the level of financial flexibility (Doidge et al., 2014). However, Altman's $Z$ Score $\left(Z=1.2 X_{1}+\right.$ $\left.1.4 X_{2}+3.3 X_{3}+0.6 X_{4}\right)$ also becomes the most popular way of measuring financial flexibility (Bancel and Mittoo, 2011). This $\mathrm{Z}$ score is composed of ratios of cash and cash equivalent to total assets, EBIT to total assets, retained earnings to total assets Market to book value to total assets and sales divided by total assets. The Z-Score 2.675 is considered green and safe zone for the firm's-Scores more than 2.67 is financially flexible firms. On the other hand, Z-Score 1.81 is considered cut off point and below this point, firms are considered inflexible and could cause bankruptcy. However-Score from 1.81 to 2.675 is considered uncertain zone but could be safe for bankruptcy for the next 2 years (James, 2016). 


\section{Mll Macrothink}

International Journal of Accounting and Financial Reporting

ISSN 2162-3082

2019, Vol. 9, No. 4

\section{Empirical Methodology}

This research endeavors to invest the impact of corporate governance on financial flexibility. The study focuses on financial flexibility based on corporate governance variables. To pursue this study researcher consider the capital structure of developing countries. However, to investigate the financial flexibility this study considers only Cement Industry of Bangladesh as a case. There are two stock exchanges are in operation in Bangladesh namely Dhaka Stock Exchange (DSE) and Chittagong Stock Exchange (CSE).There are only seven Cement companies are listed in DSE and CSE. However, only six companies' data were available for 2012-2017. We consider six companies as a case for six-year data (36 firm years) to conclude on the financial flexibility in developing countries.

\subsection{Data Sources}

The data is collected from the audited corporate annual reports published by the company's and DSE websites mine the data. We also surveyed disclosures of the two bourses and published the newspaper in Bangladesh.

\subsection{Variables}

Liquidity, unused debt capacity and Internal funds are considered as proxy of financial flexibility and applied as dependent variables while ownership concentration (OC), Board Independence (BD), Board Size (BS), Debt Capacity (DC), Firms' age (FA), Financial Constraints (FC), Growth opportunities (GOP) and Firm Size (Size) are considered as independent variable to see the relationship among variables.

Table 1. Calculation of key study variables

\begin{tabular}{lll}
\hline Abbreviation & Variable & Measurement \\
\hline OC & Ownership Concentration & $\begin{array}{l}\text { Percentage of shares held by substantial } \\
\text { interests(Shareholders }>5 \% \text { Share Holdings) }\end{array}$ \\
\hline BD & Board Dependence & Percentage of Independent directors on the board \\
\hline BS & Board Size & Number of Seats on the Board \\
\hline DC & Debt Capacity & $\begin{array}{l}\text { Tangibility/TotalAssets=(0.715*receivables }+.547 \\
* \text { inventory+.535*PPE)/Total Assets** }\end{array}$ \\
\hline UDC & Unused Debt Capacity & DC-Debt Scaled by Total Assets \\
\hline IF & Internal Funds & Retained Earnings Scaled by Total Assets \\
\hline
\end{tabular}

FA Firms Age Number of years of incorporation 


\begin{tabular}{lll} 
FC & Financial Constraints & $\begin{array}{l}\text { Altman's } \\
\text { index* }(1.2 * \mathrm{X} 1+1.4 \mathrm{X} 2+3.3 \mathrm{X} 3+06 * \mathrm{X} 4+.999 * \mathrm{X} 5\end{array}$ \\
\hline GOP & Growth Opportunity & Market to book ratio \\
\hline FS & Firm Size & Sales revenues/Total Assets \\
\hline CF & Liquidity & $\begin{array}{l}\text { Cash and Cash Equivalents-Trade Payables/Total } \\
\text { Assets }\end{array}$
\end{tabular}

$* \mathrm{X}_{1}$ represents for cash ratio (Proxy of Firms Liquidity) = Cash and Cash Equivalent less trade payables/total assets; $\mathrm{X}_{2}$ denotes retained earnings ratio=Retained earnings/total assets; $\mathrm{X}_{3}$ Indicates the profitability ratio $=\mathrm{EBIT} /$ total assets; $\mathrm{X}_{4}$ is the MTBV $=($ Book value of total assets-book value of equity) + Market value of the equity scaled by total assets and $\mathrm{X}_{5}$ represents the sales ratio $=$ Sales revenue/total assets

**Following related literature (e.g., Berger et al., 1996; Almeida and Campello, 2007), Asset Tangibility is measured as $(0.715 \times$ receivables $+0.547 \times$ inventories $+0.535 \times$ fixed capital $)$, deflated by the book value of total assets net of cash.

\subsection{Empirical Models}

$$
\begin{aligned}
\text { liquidity }_{i t} & =\alpha+\beta_{1} \mathrm{OC}+\beta_{2} \mathrm{BS}+\beta_{3} \mathrm{BD}+\beta_{4} \mathrm{IF}+\beta_{5} \mathrm{FS}+\beta_{6} \mathrm{FC}+\beta_{7} \mathrm{MTB}+\beta_{8} \mathrm{FA} \\
& +\beta_{9} \mathrm{DC}+\beta_{10} \mathrm{UDC} \varepsilon_{\mathrm{it}} \\
\mathrm{IF}_{i t}= & \alpha+\beta_{1} \mathrm{OC}+\beta_{2} \mathrm{BS}+\beta_{3} \mathrm{BD}+\beta_{4} \mathrm{CF}+\beta_{5} \mathrm{FS}+\beta_{6} \mathrm{FC}+\beta_{7} \mathrm{MTB}+\beta_{8} \mathrm{FA} \\
+ & \beta_{9} \mathrm{DC}+\beta_{10} \mathrm{UDC}+\varepsilon_{\mathrm{it}} \\
U D C_{i t} & =\alpha+\beta_{1} \mathrm{OC}+\beta_{2} \mathrm{BS}+\beta_{3} \mathrm{BD}+\beta_{4} \mathrm{CF}+\beta_{5} \mathrm{FS}+\beta_{6} \mathrm{FC}+\beta_{7} \mathrm{MTB}+\beta_{8} \mathrm{FA} \\
+ & \beta_{9} \mathrm{DC}+\varepsilon_{\mathrm{it}}
\end{aligned}
$$

Where, Liquidity is the proxy of cash flow, OC=Ownership Concentration, BS=Board Size, $\mathrm{BD}=$ Board dependency, $\mathrm{CF}=\mathrm{Cash}$ Flow, FS=Firm Size, IF=Internal Funds, UDC=Unused Debt Capacity, $\varepsilon=$ Error term.

\section{Results}

\subsection{Descriptive Statistics}

The below Pearson co-relation matrix indicates that Ownership Concentration (OC) has a positive medium correlation (0.5143) with firms' Debt Capacity (DC) and below moderate positive $(0.3746)$ correlation with financial constraints as well as firms liquidity $(0.2825)$. Moreover, it has a poor positive (0.0496) with internal funds and very poor positive $(0.0035)$ with unused debt capacity. Conversely, Ownership Concentration (OC) is negatively associated with Board Independence (BD), Board Size (BS), Firms' Age (FA) and firms' growth (MTB). 
Table 2. Pearson correlation matrix between variables

\begin{tabular}{llllllll}
\hline & year & OC & BD & BS & FA & DC & UDC \\
\hline year & 1 & & & & & & \\
\hline Ownership Concentration(OC) & -0.5368 & 1 & & & & & \\
\hline Board Independence(BD) & 0.2385 & -0.2824 & 1 & & & & \\
\hline Board Size(BS) & 0.0446 & -0.1601 & 0.0876 & 1 & & & \\
\hline Firm Age(FA) & 0 & -0.0296 & -0.3576 & 0.3121 & 1 & & \\
\hline Debt Capacity(DC) & -0.2891 & 0.5143 & -0.2251 & -0.5694 & 0.0826 & 1 & \\
\hline Unused Debt Capacity(UDC) & 0.0198 & 0.0035 & -0.2918 & 0.3113 & 0.2541 & -0.3491 & 1 \\
\hline Internal Funds(IF) & -0.201 & 0.0496 & -0.3172 & 0.0047 & 0.3465 & 0.3986 & -0.167 \\
\hline
\end{tabular}

Financial Constraints -FC

\begin{tabular}{lccccccc} 
(z-score) & -0.1227 & 0.3746 & -0.5351 & -0.2547 & -0.0349 & 0.2394 & 0.4037 \\
\hline Market to Book Value(MTB) & 0.1516 & -0.1266 & -0.3239 & 0.1364 & 0.4846 & 0.11 & -0.2137 \\
\hline Cash Flow(Liquidity) & -0.1878 & 0.2825 & -0.3359 & -0.0052 & 0.6889 & 0.1921 & 0.2381 \\
\hline
\end{tabular}

Internal

Funds Z-Score MTB Liquidity

IF(Internal Funds)

Financial Constraints(Z-score) $\quad 0.1347 \quad 1$

Market to Book Value(MTB) $\quad 0.616 \quad-0.0607 \quad 1$

$\begin{array}{lllll}\text { Liquidity(CF) } & 0.2567 & 0.192 & 0.0716 & 1\end{array}$

Board Independence (BD) has very poor positive correlation (0.0876) with board size but negative correlation with firms Age (FA), Debt capacity (DC), Unused Debt Capacity (UDC), Internal Funds (IF) but strong negative co-relation with Financial Constraints (.5351) and moderate negative correlation with Market to Book Value (MTB) and firms liquidity. 


\section{Macrothink}

International Journal of Accounting and Financial Reporting

ISSN 2162-3082

2019, Vol. 9, No. 4

Board Size has moderately (0.3121) positive association with Firms Age and Unused Debt Capacity (0.3113) as well as a poor positive relationship with internal funds (0.0047). Conversely, Board Size has a strong negative relationship (0.5694) and moderate negative relationship with Financial Constraints and weak negative relationship with Cash Flows (0.0052)

Firms' Age has strong positive correlation (0.6889) followed by MTB (0.4846) and Internal Funds (0.3986). In addition to that, it has moderated positive correlation with Debt Capacity (.0826) and Financial Constraints (0.0349). Firms Debt Capacity has a positive correlation with Internal Funds, Financial Constraints, Firms Liquidity and MTB. However, Firms' Debt capacity has a negative correlation (0.3491) with Firms' Unused Debt Capacity. Unused Debt Capacity has a positive relation (0.4037) with Financial Constraints and Firms' liquidity (.2381) while negative relationships with Internal Funds and MTB. On the other hand, MTB and Financial Constraints are positively correlated with firms' liquidity.

\subsection{Testing Hypothesis}

\subsubsection{Board Structure and Cash Holding}

Table-3 shows the model summary of the effect of the firms' Board Structure on Cash holding controlling Ownership Concentration, Market to Book Value, Unused Debt Capacity, Internal Funds, Firms' Age and Debt Capacity as predictor variables. The adjusted R Square is 0.593 indicates that $59.3 \%$ of total variability of Cash Flow is explained by independent variables.

Table 3. Model summary

Model R R Square Adjusted R Square Std. Error of the Estimate

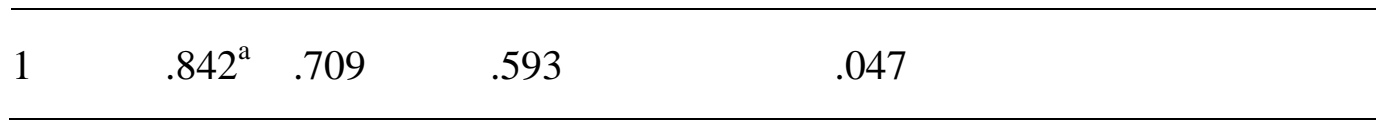

a. Predictors: (Constant), Firm Size (FS), Financial Constraints (FC), Board Size (BS), Ownership Concentration (OC), Market to Book Value (MTB), Unused Debt Capacity (UDC), Board Independency (BD), Internal Funds (IF), Debt Capacity (DC), Firm Age (FA)

Table 4. ANOVA $^{\mathrm{a}}$

\begin{tabular}{lllllll}
\hline Model & & Sum of Squares & df & Mean Square & F & Sig. \\
\hline \multirow{3}{*}{1} & Regression & .137 & 10 & .014 & 6.099 & $.000^{\mathrm{b}}$ \\
\cline { 2 - 6 } & Residual & .056 & 25 & .002 & & \\
\cline { 2 - 6 } & Total & .193 & 35 & & & \\
\hline
\end{tabular}

a. Dependent Variable: Cash Flow (CF) 
b. Predictors: (Constant), Firm Size (FS), Financial Constraints (FC), Board Size (BS), Ownership Concentration (OC), Market to Book Value (MTB), Unused Debt Capacity (UDC), Board Independency (BD), Internal Funds (IF), Debt Capacity (DC), Firm Age (FA)

Table 5 shows the relationship between firms' cash position and Board Structure holding other independent variables as the control variable. The coefficients table posits that standardized beta coefficients for Firms 'Age are 0.784 and $\mathrm{P}$ Value is 0.001 . The beta coefficients for Market to Book Value (MTB) is $2^{\text {nd }}$ highest $(0.404)$ having P Value is 0.027. Therefore these two variables have a significant influence on firms' cash position. Consequently, this result concludes that Board Structure has no significant influence on firms' cash holding.

Table 5. Relationship between board structure and firms' cash position

\section{Coefficients $^{\mathrm{a}}$}

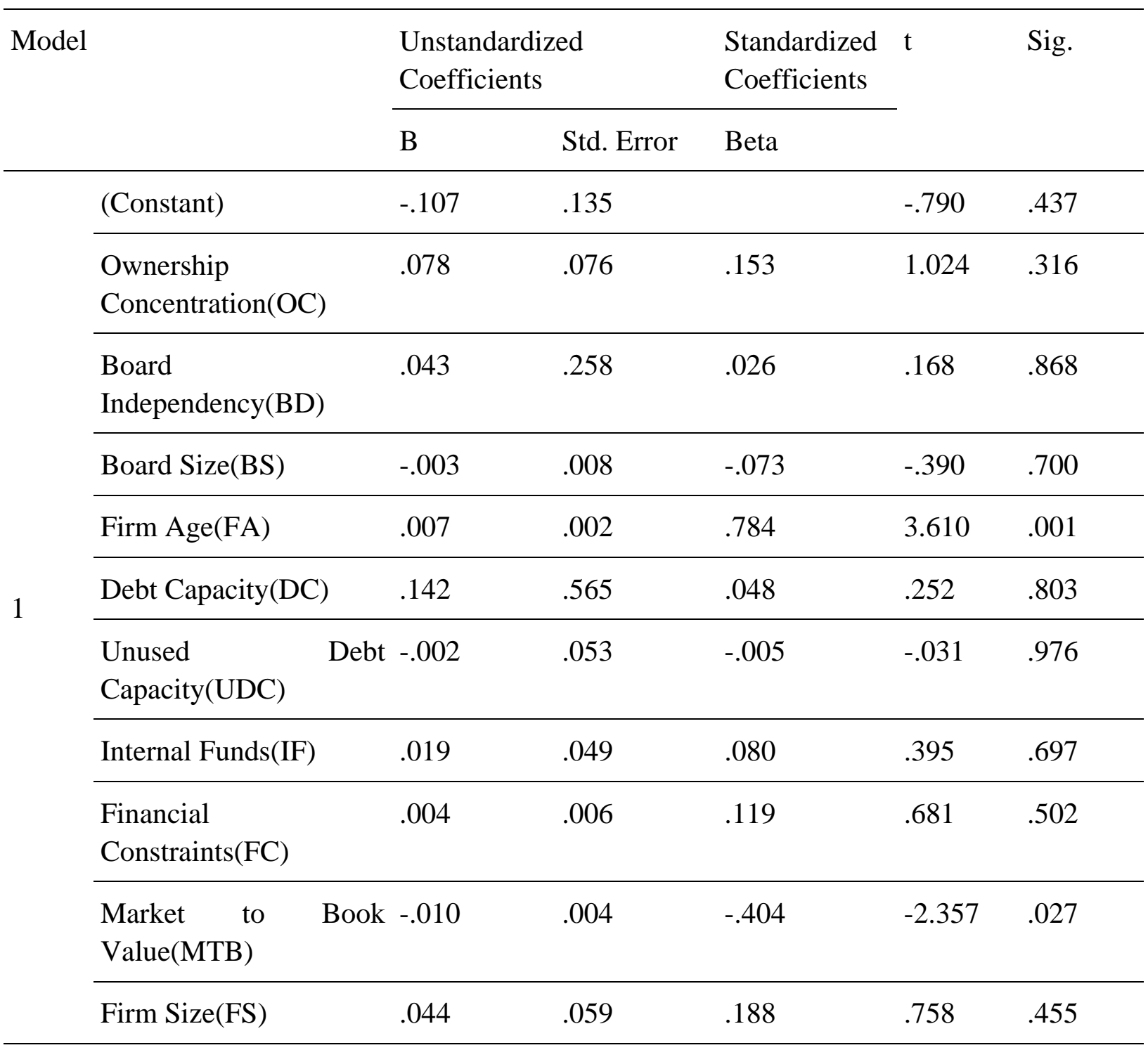

a. Dependent Variable: Cash Flow (CF) 


\section{Ml Macrothink}

International Journal of Accounting and Financial Reporting

ISSN 2162-3082 2019, Vol. 9, No. 4

\subsubsection{Firm Size and Internal Funds}

Tables 6, 7, 8 provide analysis the relationship between Firms' Size and Internal Funds. The model summary table shows that $60.4 \%$ variability of Internal Funds is explained by Independent variables used in the model

Table 6. Model summary for internal funds and firm size

\begin{tabular}{lllll}
\hline Model & $\mathrm{R}$ & R Square & Adjusted R Square & Std. Error of the Estimate \\
\hline 1 & $.847^{\mathrm{a}}$ & .717 & .604 & .191
\end{tabular}

a. Predictors: (Constant), Firm Size (FS), Financial Constraints (FC), Board Size (BS), Ownership Concentration (OC), Market to Book Value (MTB), Unused Debt Capacity (UDC), Board Independency (BD), Cash Flow (CF), Debt Capacity (DC), Firm Age (FA)

Table 7. ANOVA ${ }^{\mathrm{a}}$

\begin{tabular}{|c|c|c|c|c|c|c|}
\hline Model & & Sum of Squares & $\mathrm{df}$ & Mean Square & $\mathrm{F}$ & Sig. \\
\hline \multirow{3}{*}{1} & Regression & 2.320 & 10 & .232 & 6.337 & $.000^{\mathrm{b}}$ \\
\hline & Residual & .915 & 25 & .037 & & \\
\hline & Total & 3.235 & 35 & & & \\
\hline
\end{tabular}

a. Dependent Variable: Internal Funds (IF)

b. Predictors: (Constant), Firm Size (FS), Financial Constraints (FC), Board Size (BS), Ownership Concentration (OC), Market to Book Value (MTB), Unused Debt Capacity (UDC), Board Independency (BD), Cash Flow (CF), Debt Capacity (DC), Firm Age (FA)

Table 8. Relationships between internal funds and firm size

\begin{tabular}{|c|c|c|c|c|c|c|}
\hline \multirow{2}{*}{\multicolumn{2}{|c|}{ Model }} & \multicolumn{2}{|c|}{$\begin{array}{l}\text { Unstandardized } \\
\text { Coefficients }\end{array}$} & \multirow{2}{*}{$\begin{array}{l}\text { Standardized } \\
\text { Coefficients } \\
\text { Beta }\end{array}$} & \multirow[t]{2}{*}{$\mathrm{t}$} & \multirow[t]{2}{*}{ Sig. } \\
\hline & & B & Std. Error & & & \\
\hline \multirow[b]{2}{*}{1} & (Constant) & -1.225 & .496 & & -2.472 & .021 \\
\hline & $\begin{array}{l}\text { Ownership } \\
\text { Concentration(OC) }\end{array}$ & -.446 & .303 & -.213 & -1.474 & .153 \\
\hline
\end{tabular}


Unstandardized

Coefficients

Standardized $\mathrm{t}$

Coefficients

Sig.

B Std. Error Beta

\begin{tabular}{|c|c|c|c|c|c|}
\hline $\begin{array}{l}\text { Board } \\
\text { Independency(BD) }\end{array}$ & .443 & 1.039 & .065 & .426 & .674 \\
\hline Board Size(BS) & .086 & .029 & .469 & 2.922 & .007 \\
\hline Firm Age(FA) & -.016 & .008 & -.456 & -1.840 & .078 \\
\hline Debt Capacity(DC) & 3.942 & 2.146 & .322 & 1.837 & .078 \\
\hline $\begin{array}{l}\text { Unused } \\
\text { Capacity(UDC) }\end{array}$ & Debt-.004 & .215 & -.003 & -.019 & .985 \\
\hline $\begin{array}{l}\text { Financial } \\
\text { Constraints }(\mathrm{FC})\end{array}$ & .045 & .023 & .311 & 1.920 & .066 \\
\hline $\begin{array}{l}\text { Market to } \\
\text { Value(MTB) }\end{array}$ & Book.044 & .017 & .420 & 2.513 & .019 \\
\hline Cash Flow $(\mathrm{CF})$ & .318 & .806 & .078 & .395 & .697 \\
\hline Firm Size(FS) & .694 & .195 & .717 & 3.555 & .002 \\
\hline
\end{tabular}

a. Dependent Variable: Internal Funds (IF)

The above Table 8 illustrates the relationship between Internal Funds and Firm's Size. The results shows that Firm Size has highest standardized coefficients $(0.717)$ followed by Firms Age (0.456), Debt Capacity (0.322) and corresponding P Value 0.002, 0.078, and 0.078. These three variables have a significant influence on firms' Internal Funds. Other variables have insignificant influence on Firms' Internal Funds. As a result, this research supports our hypothesis that firm size has a positive relationship with Internal Funds.

\subsubsection{Ownership Structure (OC) and Unused Debt Capacity (UDC)}

Tables 9, 10 and 11 show the data analysis regarding the ownership Structure and Unused Debt Capacity holding other variables as a control variable. The model summary posits that $56.9 \%$ Variability Unused Debt Capacity is explained by Independent Variables used in the model. 
Table 9. Model summary

\begin{tabular}{lllll} 
Model & $\mathrm{R}$ & R Square & Adjusted R Square & Std. Error of the Estimate \\
\hline 1 & $.754^{\mathrm{a}}$ & .569 & .396 & .178 \\
\hline
\end{tabular}

a. Predictors: (Constant), Firm Size (FS), Financial Constraints (FC), Board Size (BS), Ownership Concentration (OC), Market to Book Value (MTB), Board Independency (BD), Cash Flow (CF), Debt Capacity (DC), Internal Funds (IF), Firm Age (FA)

Table 10. ANOVA ${ }^{\mathrm{a}}$

\begin{tabular}{|c|c|c|c|c|c|c|}
\hline Model & & Sum of Squares & Df & Mean Square & $\mathrm{F}$ & Sig. \\
\hline \multirow{3}{*}{1} & Regression & 1.043 & 10 & .104 & 3.298 & $.007^{\mathrm{b}}$ \\
\hline & Residual & .791 & 25 & .032 & & \\
\hline & Total & 1.834 & 35 & & & \\
\hline
\end{tabular}

a. Dependent Variable: Unused Debt Capacity (UDC)

b. Predictors: (Constant), Firm Size (FS), Financial Constraints (FC), Board Size (BS), Ownership Concentration (OC), Market to Book Value (MTB), Board Independency (BD), Cash Flow (CF), Debt Capacity (DC), Internal Funds (IF), Firm Age (FA)

Table 11. Relationship between ownership structure and unused debt capacity Coefficients

\begin{tabular}{|c|c|c|c|c|c|c|}
\hline \multicolumn{2}{|c|}{ Model } & \multicolumn{2}{|c|}{$\begin{array}{l}\text { Unstandardized } \\
\text { Coefficients }\end{array}$} & \multirow{2}{*}{$\begin{array}{l}\text { Standardized } \\
\text { Coefficients } \\
\text { Beta }\end{array}$} & \multirow[t]{2}{*}{$\mathrm{t}$} & \multirow[t]{2}{*}{ Sig. } \\
\hline & & B & Std. Error & & & \\
\hline \multirow{4}{*}{1} & (Constant) & -.438 & .506 & & -.866 & .395 \\
\hline & $\begin{array}{l}\text { Ownership } \\
\text { Concentration(OC) }\end{array}$ & -.157 & .292 & -.100 & -.539 & .594 \\
\hline & $\begin{array}{l}\text { Board } \\
\text { Independency(BD) }\end{array}$ & -.980 & .949 & -.191 & -1.032 & .312 \\
\hline & Board Size(BS) & .028 & .031 & .206 & .911 & .371 \\
\hline
\end{tabular}




\begin{tabular}{|c|c|c|c|c|c|c|}
\hline Firm Age(FA) & & .011 & .008 & .425 & 1.349 & .189 \\
\hline Debt Capacity(DC) & & -1.600 & 2.101 & -.173 & -.761 & .454 \\
\hline Internal Funds(IF) & & -.004 & .186 & -.005 & -.019 & .985 \\
\hline $\begin{array}{l}\text { Financial } \\
\text { Constraints(FC) }\end{array}$ & & .045 & .021 & .420 & 2.130 & .043 \\
\hline $\begin{array}{l}\text { Market to } \\
\text { Value(MTB) }\end{array}$ & Book & -.031 & .017 & -.398 & -1.840 & .078 \\
\hline Cash Flow(CF) & & -.023 & .751 & -.008 & -.031 & .976 \\
\hline Firm Size(FS) & & -.122 & .221 & -.167 & -.550 & .587 \\
\hline
\end{tabular}

a. Dependent Variable: Unused Debt Capacity (UDC)

The above table shows the relationship between Ownership Structure and Unused Debt Capacity of the firms'. The table reports that Financial Constraints has the standardized beta coefficients (0.420) and Market to Book Value has (0.398) with P Value 0.043 and 0.078 respectively. Only Financial Constraints and Market to Book Value have a positive significant impact on firms' unused debt capacity. Therefore, this research does not support the hypothesis that Ownership Structure has a positive relation with Firms' Unused Debt Capacity.

Table 12. Summary of multiple OLS regression
Dependent Variable
(1)
(2)
(3)

\begin{tabular}{llll}
\hline (Financial Flexibility) & liquidity & Internal Funds(IF) & $\begin{array}{l}\text { Unused } \\
\text { Capacity(UDC) }\end{array}$ \\
\hline Independent Variable & & & Debt \\
\hline Ownership Structure(OC) & 0.124 & -0.503 & -0.179 \\
\hline Board Independence(BD) & 0.201 & -0.0675 & $(-0.63)$ \\
\hline & -1.52 & $(-1.38)$ & -0.905 \\
\hline
\end{tabular}




\begin{tabular}{|c|c|c|c|}
\hline Board Size(BS) & -0.00895 & 0.0525 & 0.0377 \\
\hline & $(-1.16)$ & -1.57 & -1.47 \\
\hline \multirow[t]{2}{*}{ Firms'Age } & $0.00647 * * *$ & -0.00356 & 0.0087 \\
\hline & -5.17 & $(-0.38)$ & -1.26 \\
\hline \multirow[t]{2}{*}{ Debt Capacity(DC) } & 0.23 & $6.091^{*}$ & -1.637 \\
\hline & -0.37 & -2.46 & $(-0.79)$ \\
\hline \multirow[t]{2}{*}{ Unused Debt Capacity(UDC) } & 0.0441 & -0.109 & \\
\hline & -0.82 & $(-0.42)$ & \\
\hline \multirow[t]{2}{*}{ Internal Funds(IF) } & -0.000611 & & -0.0633 \\
\hline & $(-0.02)$ & & $(-0.42)$ \\
\hline \multirow[t]{2}{*}{ Altsman Z Score } & 0.00243 & 0.0269 & $0.0508 *$ \\
\hline & -0.39 & -0.98 & -2.71 \\
\hline \multirow[t]{2}{*}{ Market to Book Ratio } & & $0.0537^{*}$ & -0.0302 \\
\hline & & -2.6 & $(-1.81)$ \\
\hline \multirow[t]{2}{*}{ Cash Flow(Liquidity) } & & 1.007 & -0.0859 \\
\hline & & -1.07 & $(-0.12)$ \\
\hline \multirow[t]{2}{*}{ Constant } & -0.0818 & -0.632 & -0.587 \\
\hline & $(-0.64)$ & $(-1.13)$ & $(-1.39)$ \\
\hline $\mathrm{N}$ & 36 & 36 & 36 \\
\hline
\end{tabular}

T statistics in parentheses: * $\mathrm{p}<0.05, * * \mathrm{p}<0.01, * * * \mathrm{p}<0.001$ 


\section{Conclusion}

Financial flexibility appears to be the most important factor that is being considered by financial managers for making capital structure decision. To date studies conducted in this area mostly covered how to get financial flexibility and paid attention to cash holding, leverage, payout choices etc. but scant of researches have been conducted and published the impact of corporate governance on financial flexibility. Moreover, cash holding, leverage position, financial constraints are proxies as financial flexibility and tested in developed countries like the UK, US, and Canada etc. However, the business environment, nature of the business and business culture across the world may vary and affect the financial flexibility where developing countries have received very few attention and demands for testing financial flexibility. This is due to the literature that suggests financial flexibility is more important in developing countries than in developed countries owing to information asymmetry

Therefore, there are many questions that have not received an adequate amount of attention. However, Anecdotal evidence posits that corporate governance has a positive impact on financial performance and a financially flexible firm enacts positively when the firm has financial constraints and performs better than inflexible firms. Aligning with this argument we endeavor to investigate the impact of corporate governance on financial flexibility.

The objectives of this study were to investigate the relationship between corporate governance financial flexibility; how corporate governance influence financial flexibility; and, what factors of corporate governance are dominant to influence financial flexibility. To pursue the research objectives we chose Cement Industry as a case. There are seven companies including two multinational companies listed in the Dhaka and Chittagong Stock exchange. We consider six companies six years (2012-2017) data to come to a conclusion. We choose cement industry there is a good combination of national and international companies that may predict better research outcome. We exclude one company due to the availability of data. The data has been collected from corporate annual reports obtained from DSE and CSE and Companies websites. To analyze the data we have used statistical software SPSS and STATA

This research concludes that Board Structure has no significant influence on firms' cash holding. However, Firms Age and Market to Book Value have a significant influence on firms' cash position. This study also finds that Ownership Structure has no positive impact on Firms' Unused Debt Capacity but Financial Constraints and Market to Book Value have a positive significant impact on firms' unused debt capacity. However, Firm Size has a positive relationship with Internal Funds.

\section{References}

Arslan, Ö., Florackis, C., \& Ozkan, A. (2014). Financial flexibility, corporate investment, and performance: Evidence from financial crises. Review of Quantitative Finance and Accounting, 42(2), 211-50. 


\section{$\triangle 1$ Macrothink}

International Journal of Accounting and Financial Reporting

ISSN 2162-3082

2019, Vol. 9, No. 4

Bancel, F., \& Mittoo, U. R. (2011). Financial flexibility and the impact of the global financial crisis: Evidence from France. International Journal of Managerial Finance, 7(2), 179-216.

Bates, T. W., Kahle, K. M., \& Stulz, R. M. (2008). Why do US firms hold so much more cash than they used to?. J. Finance, 64, 1985-2021.

Beatty, A., Liao, S., \& Weber, J. (2010). Financial reporting quality, private information,monitoring, and the lease-versus-buy decision. Account Rev., 85, 1215-1238.

Byoun, S. (2008). How and when do firms adjust their capital structures toward targets?. Journal of Finance, 63(6), 3069-3096.

Campello, M., Graham, J. R., \& Harvey, C. R. (2010). The real effects of financial constraints: evidence from a financial crisis. J. Financ Econ, 97, 470-487.

Cherkasova, V., \& Kuzmin, E. (2018, May-August). Financial Flexibility as an Investment Efficiency factor in Asian Companies. Gadjah Mada International Journal of Business, 20(2), 137-164.

Claessens, S., \& Laeven, L. (2003). Financial Development, Property Rights, and Growth. The Journal of Finance, 58(6), 2401-36.

Daniel, N. D., Denis, D. J., \& Naveen, L. (2010). Sources of financial flexibility: Evidence from cash flow shortfalls. Working paper, Philadelphia, PA, Drexel University.

DeAngelo, H., \& DeAngelo, L. (2007). Capital structure, payout policy, and financial flexibility. Working paper, Marshall School of Business.

Devos, E., \& Rahman, S. (2014). Location and lease intensity. Journal of Corporate Finance, 29, 20-36.

Dewri, L. V., Islam, M. R., \& Arifuzzaman, S. M. (2015). Behavioral Analysis of Investors' Attitude towards Dividend Declaration in Developing Country - A Case of Bangladesh. International Journal of Business and Management, 10(11).

Drobetz, W., \& Wanzenried, G. (2006). What determines the speed of adjustment to the target capital structure?. Applied Financial Economics, 16, 941-958.

Eisfeldt, A., \& Rampini, A. (2009). Leasing, ability to repossess, and debt capacity. Rev. Financ. Stud., 22, 1621-1657.

Estwick, T. (2016). Principal-Principal Agency and Financial Flexibility in Transition Economies. Journal of Business Inquiry, 15(1).

Gamba, A., \& Triantis, A. (2008). The value of financial flexibility. Journal of Finance, 63(5), 2263-96.

Graham, J., Lemmon, M., \& Schallheim, J. (1998). Debt, leases, taxes, and the endogeneity of corporate tax status. J. Finance, 53, 131-162. 


\section{Macrothink}

International Journal of Accounting and Financial Reporting

ISSN 2162-3082

2019, Vol. 9, No. 4

Harford, J. (2008). Corporate governance and firm cash holdings in the US. Journal of Financial Economics, 87(3), 535-555.

Hsien-Chang Kuo, H. C., Li, Y., Wang, L. H., \& Ding, C. Y. (2006). Flexibility and Performance of MNEs: Evidence from Taiwan. International Journal of Business, 11(4).

Islam, M., Wang, M., \& Dewri, L. (2019). Financial Flexibility-A Synthesis Review of Literature. International Journal of Accounting and Financial Reporting, 9(1).

James, M. (2016). Financial Flexibility and the Impact of the 2007/2008 Global Financial Crisis: Evidence from African Firms. Research Journal of Finance and Accounting, 7(8).

Jensen, M., \& Meckling, W. (1976). The theory of the Firm: Managerial Behaviour, Agency Costs, and Ownership Structure. Journal of Financial Economics, 3(4), 305-360.

Kao, S. W. (2012). Research note: Cash holding and firm value: the case of Taiwan's tourism industry. Tourism Economics, 18(4), 897-902.

Kim, C.-S., Mauer, D., \& Sherman, A. (1998). The Determinants of Corporate Liquidity: Theory and Evidence. Journal of Financial and Quantitative Analysis, 33, 335-359.

Lee, K. W., \& Lee, C. F. (2009). Cash holdings, corporate governance structure and firm valuation. Review of Pacific Basin Financial Markets and Policies, 12(3), 475-508.

Liu, Z. (2017, May). Financial Flexibility and Financial Policy. Educational Research International, 6(2).

Ma, C., \& Jin, Y. (2016). What Drives the Relationship Between Financial Flexibility and Firm Performance: Investment Scale or Investment Efficiency? Evidence from China. Emerging Markets Finance \& Trade, 52, 2043-2055.

Matthew, T. B., \& Garfinkel, J. A. (2004, October). Financial Flexibility and the Cost of External Finance for U.S. Bank Holding Companies. Journal of Money, Credit and Banking, $36(5), 827-852$.

Mills, L. F., \& Newberry, K. J. (2005, May). Firms' Off-Balance Sheet and Hybrid Debt Financing :Evidence from Their Book-Tax Reporting Differences. Journal of Accounting Research, 43(2).

Mittoo, U. R., \& Bancel, F. (2009). Why do European firms go public?. European Financial Management, 15(4), 844-884.

Myers, S. C., \& Majluf, N. S. (1984). Corporate financing and investment decisions when firms haveinformation that investors do not have. Journal of Financial Economics, 13, 187-221.

Opler, T., Pinkowitz, R., Stulz, R., \& Williamson, R. (1999). The determinants and implications of corporate cash holdings. Journal of Financial Economics, 52, 3-46.

Simutin, M. (2010). Excess cash and stock returns. Financial Management, 9(3), 1197-1222. 


\section{Macrothink}

International Journal of Accounting and Financial Reporting ISSN 2162-3082

Tong, H., \& Wei, S.-J. (2008). Real effects of the subprime mortgage crisis: is it a demand or a finance shock?. Working Paper 14205, National Bureau of Economic Research.

World Bank. (2015). Global financial development report 2015-2016: Long-term finance. World Bank Group.

\section{Note}

Note 1. Concentrated ownership is associated with inflated earnings, whereas dispersed ownership with extraction of private benefits of control (Coffee, 2005).

\section{Copyright Disclaimer}

Copyright for this article is retained by the author(s), with first publication rights granted to the journal.

This is an open-access article distributed under the terms and conditions of the Creative Commons Attribution license (http://creativecommons.org/licenses/by/4.0/) 